\title{
Effect of Organic Fertilization on Fruit Set, Dropping, Yield and Fruit Quality
} of Washington Navel Orange

Samra, N. R. ${ }^{1}$; M. I. EL-Kady; A. R. Hikal ${ }^{2}$ and M. S. H. Ghanem ${ }^{2}$.

${ }^{1}$ Pomology Dept., Fac. Agric., Mans. univ., Egypt.

${ }^{2}$ Citrus Res. Dept., Horti. Res. inst., Agric .Res. center, Giza, Egypt. ABSTRACT

This study was carried out during the seasons of 2014, 2015 on Washington navel orange (Citrus sinensis L. Osbeck) cultivated in a commercial orchard located in Shiwah Valley near Aga city, Dakahleia Governorate, Egypt. to study the effect of organic fertilization such as humic and Fulvic acid as a soil application on fruit set, dropping and yield of Washington navel orange. The data reveal that adding humic or fulvic acid each alone or together significantly increased the fruit set percentage but reduced pre-harvest drop than the control. The data also, showed that adding humic acid at $30 \mathrm{ml}$ with fulvic acid at $100 \mathrm{ml}$ significantly increased the number of fruit per trees than the other treatments or the control since, this treatment gave a higher yield. Whereas no clear effect had obtained on average fruit weight. Furthermore, both humic or fulvic acid applications gave no clear effect on average fruit juice than the control. So, this treatment gave no clear effect on SSC, total acidity and SSC/acid ratio in fruit juice than the control. but , thes treatment gave a somewhat increment on average Vit-c in fruit juice.

Keywords: organic fertilization, humic acid, fulvic acid, fruit set, dropping, yield.

\section{INTRODUCTION}

Citrus is one of the most important cash crops especially under warm temperate regions, it occupied the third position between fruit crops after grapes and apples. Citrus area in Egypt increased rapidly from year to another due to its importance for local consumption, its highly economic value as a main exportation fruit to the European countries and the Gulf States. In Egypt Washington navel orange (Citrus sinensis L. Osbeck) ranked first among the species of citrus. It occupies about $35 \%$ of the total cultivated area of fruits and, its acreage reached 440.706 feddan, which produce about 4.402.180 metric tons according to Ministry of Agriculture, (2014). Washington Navel orange is the most favorite cultivar in Egypt and it is considered a popular fresh fruits due to seedless, large size, nutritive value, flavor and aroma characteristic. it is also an important source of early season income for citrus growers at some commercial citrus areas of the world .

Cost of mineral fertilizers has been significantly going up. As a result, it has become necessary to seek alternatives that would supply the poor soil with more economic sources of fertilizers (Rodriguez, 2000). So, there is growing interest of the use of humic and fulvic acid as a substitute to chemical fertilizers which have potential polluting effects in the environment (Senn and Kingman, 2000) Use of bio-fertilizers like humic and fulvic acid among these non-conventional sources engrosses prominent position in organic matter deficit soils. Supplementation of these bio-stimulants enhances the fertilizer use efficiency by creating conducive environment for efficacious plant growth (Arancon et al., 2006).

Bio-fertilizers are easy and safe to handle with field applications and it is very safe for human, animal and environment that improved their efficiency in increasing crop yields and decreasing the costs of some agricultural practices. It may not replace mineral fertilizers, but significantly reduce their rate of application (Ishac, 1989 and Saber, 1993).

Bio-stimulants have been described as "nonnutritional products that may reduce fertilizer use and increase yield and resistance to water and temperature stresses "which have been shown to increase plant shoot and root growth, and uptake of some nutrients (Russo \& Berlyn, 1992 and Poincelot, 1993).

Humic substances are extremely complex heterogenous mixtures ( MacCarthy et al., 1990). Fulvic acid is a part of the humic substances in soil rich in organic matter mainly consists of humic and fulvic acids which are called humin materials( Schnitzer, M., 1982., Andriesse, J.P., 1988). Humic substances such as humic acid, fulvic acid, are the major components (65$70 \%$ ) of soil organic matter (Cacco and Dell Agnolla, 1984).

Fulvic acid (FA) molecules can readily enter plant roots, stems, and leaves. As they enter these plant parts they carry trace minerals from plant surfaces into plant tissues and. it has ability to readily bond minerals and elements into its molecular structure causing them to dissolve and become mobilized fulvic complexes cells (Nardi et al., 2002) Fulvic acid is soluble in water at all $\mathrm{pH}$ conditions (acidic, neutral and alkaline) while humic acid is not soluble in water under acid conditions. (Malcolm, 1990).

This study aimed to investigate the effect of some biostimulants ( humic and fulvic acid) on fruit set ,dropping , yield and fruit quality of Washington Navel orange trees.

\section{MATERIALS AND METHODS}

This study was carried out during the seasons of 20013, 20014 on Washington navel orange (Citrus sinensis L. Osbeck) cultivated in a commercial orchard located in Shiwah Valley near Aga city, Dakahleia Governorate, Egypt. Trees were about 25 years old, spaced at $5 \times 5$ meters aparts . budded on sour orange root stock (C. aurantium , L) Seventy-two trees were chosen for the present study almost uniform in vigor and apparently healthy and subjected to the normal cultural practices. The experiment was arranged in a complete randomized block design with nine treatments replicated four times and each treatments and each replicate was presented by two trees as shown from Table (1)

All treatments were applied on two equal doses in February and august during the two seasons of the study 
Soil samples were taken to determine the properties of experimental soil at three depths from soil surface, 0 to $30 \mathrm{~cm}, 30$ to $60 \mathrm{~cm}$ and 60 to $90 \mathrm{~cm}$. Samples in each category were completely mixed and subjected to mechanical and chemical analysis of soil as included in Table 2

Table 1. The applied treatments

\begin{tabular}{lc}
\hline No & Applied treatment \\
\hline 1 & Control treated with tap water only \\
2 & Humic acid at $30 \mathrm{ml}$ \\
3 & Humic acid at $60 \mathrm{ml}$ \\
4 & Fulvic acid at $\mathrm{ml}$ \\
5 & Fulvic acid at $100 \mathrm{ml}$ \\
6 & Humic acid at $30+$ Fulvic acid at $50 \mathrm{ml}$ \\
7 & Humic acid at $30+$ Fulvic acid at $100 \mathrm{ml}$ \\
8 & Humic acid at $60+$ Fulvic acid at $50 \mathrm{ml}$ \\
9 & Humic acid at $60+$ Fulvic acid at $100 \mathrm{ml}$ \\
\hline
\end{tabular}

Table 2. Mechanical and chemical analysis of experimental soil.

\begin{tabular}{llc}
\hline Soil characters & & \\
\hline & Course sand & 1.8 \\
& Fine sand & 18.9 \\
Mechanical analysis (\%) & Silt & 32.4 \\
& Clay & 46.9 \\
& Texture class & Clay \\
\hline E.C (1:5) ds,m ${ }^{-1}$ & & 1.13 \\
PH & & 7.79 \\
CaCo3 \% & & 2.87 \\
O.M \% & & 1.76 \\
Sp \% & & 63.5 \\
& $\mathrm{~N}$ & 43.4 \\
& $\mathrm{PH}$ & 5.16 \\
Available (mg/kg) & $\mathrm{K}$ & 295 \\
& $\mathrm{Fe}$ & 14.8 \\
& $\mathrm{Mn}$ & 7.9 \\
& $\mathrm{Zbn}$ & 1.07 \\
\hline
\end{tabular}

1 -Fruit set and drop percentage:-

1- Fruit set percentage:-

Four secondary branches of four sides for each treated tree were randomly chosen labeled and calculated initial fruit set $\%$ at full bloom stage in both seasons 2013 and 2014 respectively, using the following equitation

$$
\begin{aligned}
& \text { A - Initial fruit set } \%=\frac{\text { Fruit set numbers after petal fall }}{\text { Total flowers number }} \times 100 \\
& \text { B - Final fruit set } \%=\frac{\text { Fruits number at end of June }}{\text { Total flowers number }} \times 100 \\
& 2 \text { - Preharvest drop : }
\end{aligned}
$$

During the seasons the following parameters were carried out after June drop (at the first week of June) the number of remaining fruits was counted to estimated June drop The June drop percentage was calculated by using the following equitation

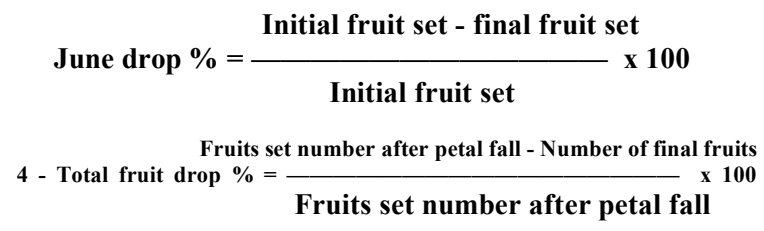

\section{5 - Preharvest $=$ Total fruit drop - June drop}

Harvest date was carried out in mid December when SSC/acid ratio in fruit juice about 9-10\% according to (El- Nabawy, 1967) and when the fruit have been yellow colour during the both seasons

2- Number of fruit and Yield/tree (kg/tree)

At harvest time, yield was calculated as $\mathrm{kg} /$ tree by multiplication number of fruits per tree $\mathrm{x}$ average fruit weight. At harvest ten fruits from each replicate were randomly collected in mid December to determine both physical and chemical properties of fruit as the follows.

\section{A - Fruit chemical characteristics}

1- soluble solids content (SSC)\%

It was expressed by using carlzesis hand refractometer 2- Total acidity content $\%$

It was determined by titrating $10 \mathrm{ml}$ juice From each sample using $\mathrm{NaoH}(0.1 \mathrm{~N})$ phenolphthalein(ph.th) as an indicator. the acidity was expressed as gm of citric acid $/ 100 \mathrm{ml}$ juice according to A.O.A.C (1995)

\section{3- soluble solids/acid ratio}

This ratio was calculated by the percent age of SSC on total acidity to be used as a criterion for maturity determination.

\section{4- Ascorbic acid (vitamin C)}

It was determined by using 2,6 dichlorophenol indophenol dye $2 \%$ oxalic as a subtract. Vitamin C content was calculated as $\mathrm{mg} / 100 \mathrm{ml}$ juice (A.O.A.C (1995)

\section{Statistical analysis}

All data of the study, randomized complete block design was used and the data pertaining to various parameters were analyzed by ANOVA techniques using CoStat Computer Software.

The obtained data of both seasons were subjected to analysis of variance according to the means were differentiated using Duncan multiple range test at $5 \%$ level (Duncan, 1965).

\section{RESULT AND DISCUSSION}

This investigation was carried out during two seasons of 2014, 2015 on Washington navel orange (Citrus sinensis L. Osbeck) to study the effect of organic fertilization such as humic and Fulvic acid as a soil application on fruit set, dropping and yield of Washington navel orange. the obtained result are presented as follow :-

1- Effect of humic and Fulvic acid on Fruit set and dropping of Washington navel orange fruits

Data from Table (3 )showed that humic or fulvic acid application each

alone or together significantly increased average fruit set percentage. than the control .Furthermore, adding humic acid at $30 \mathrm{ml}$ with fulvic acid at 50 or $100 \mathrm{ml}$ gave a higher fruit set than each alone or the untreated trees Since, application of humic acid at $30 \mathrm{ml}$ with fulvic at $50 \mathrm{ml}$ gave higher significant effect on fruit set. This result confirm the result which obtained by Fathy, et al., (2010) , Fayed, (2010), Salem, et al., (2010), Sharaf, et al. (2011) and Mosa et al. (2015) 
Table 3. Effect of humic and fulvic acid on fruit set and dropping of Washington navel orange fruits

\begin{tabular}{|c|c|c|c|c|c|c|c|}
\hline & \multicolumn{3}{|c|}{ final Fruit set $\%$} & \multicolumn{3}{|c|}{ Preharvest drop } \\
\hline & & \multicolumn{2}{|c|}{$2014 \quad 2015$} & \multirow{2}{*}{$\frac{\text { Mean }}{2.46}$} & \multirow{2}{*}{$\frac{\mathbf{2 0 1 4}}{30.83 \mathrm{a}}$} & \multirow{2}{*}{$\frac{\mathbf{2 0 1 5}}{23.72 \mathrm{ab}}$} & \multirow{2}{*}{$\frac{\text { Mean }}{27.28}$} \\
\hline $\begin{array}{l}\text { Treatments } \\
1\end{array}$ & Treatments & $2.52 \mathrm{abc}$ & $2.39 \mathrm{c}$ & & & & \\
\hline \multicolumn{2}{|r|}{ Humic at $30 \mathrm{ml}$} & $2.35 \mathrm{bc}$ & $3.41 \mathrm{bc}$ & 2.88 & \multirow{2}{*}{$\begin{array}{c}17.26 \mathrm{a} \\
9.39 \mathrm{a}\end{array}$} & $19.35 \mathrm{abc}$ & 18.31 \\
\hline \multicolumn{2}{|r|}{ Humic at $60 \mathrm{ml}$} & $2.84 \mathrm{ab}$ & $3.36 \mathrm{bc}$ & 3.10 & & $15.15 \mathrm{abc}$ & 12.27 \\
\hline \multicolumn{2}{|r|}{ Fulvic at $50 \mathrm{ml}$} & $1.95 \mathrm{c}$ & $2.89 \mathrm{bc}$ & 2.42 & $8.15 \mathrm{a}$ & $9.39 \mathrm{bc}$ & 8.77 \\
\hline 5 & Fulvic at $100 \mathrm{ml}$ & $2.04 \mathrm{c}$ & $3.25 \mathrm{bc}$ & 2.65 & $8.33 \mathrm{a}$ & $5.59 \mathrm{c}$ & 6.96 \\
\hline 6 & Humic at $30 \mathrm{ml}+$ Fulvic at $50 \mathrm{ml}$ & $3.16 \mathrm{a}$ & $4.67 \mathrm{a}$ & 3.92 & $16.67 \mathrm{a}$ & $23.14 \mathrm{a}$ & 19.91 \\
\hline 7 & Humic at $30 \mathrm{ml}+$ Fulvic at $100 \mathrm{ml}$ & $2.55 \mathrm{abc}$ & $3.73 \mathrm{ab}$ & 3.14 & $7.72 \mathrm{a}$ & $15.38 \mathrm{abc}$ & 11.55 \\
\hline 8 & Humic at $60 \mathrm{ml}+$ Fulvic at $50 \mathrm{ml}$ & $2.01 \mathrm{c}$ & $2.54 \mathrm{bc}$ & 2.28 & $13.39 \mathrm{a}$ & $19.49 \mathrm{abc}$ & 16.44 \\
\hline \multirow[t]{2}{*}{9} & Humic at $60 \mathrm{ml}+$ Fulvic at $100 \mathrm{ml}$ & $3.12 \mathrm{ab}$ & $2.93 \mathrm{bc}$ & 3.03 & $11.67 \mathrm{a}$ & $20.73 \mathrm{abc}$ & 16.20 \\
\hline & & 0.72 & 1.08 & --- & N.S & 15.28 & ---- \\
\hline
\end{tabular}

Furthermore, data from Table (3) showed that adding humic acid each alone or in combination reduced the preharvest drop than the control, The data also showed that, Fulvic acid alone at 50 or $100 \mathrm{ml}$ reduced preharvest drop significantly than the control especially at the first seasons of the study.
Effect of humic and Fulvic acid on number of fruit and yield of Washington navel orange trees:

Data from Table (4) show clearly that concerning the effect of humic and Fulvic acid each alone or in a combination on number of fruits per tree data from table (4) reveled that adding humic acid at $60 \mathrm{ml}$ and fulvic adding $100 \mathrm{ml}$ significantly increase the number of fruit per tree than those adding humic or fulvic each alone or the untreated trees.

Table 4. Effect of humic and Fulvic acid on number of fruit and yield of Washington navel orange trees

\begin{tabular}{|c|c|c|c|c|c|c|c|c|c|c|}
\hline \multirow{2}{*}{\multicolumn{2}{|c|}{ Treatments }} & \multicolumn{3}{|c|}{ No of fruits / tree } & \multicolumn{3}{|c|}{ Fruit weight (g) } & \multicolumn{3}{|c|}{ Yield (kg) / tree } \\
\hline & & 2014 & 2015 & Mean & 2014 & 2015 & Mean & 2014 & 2015 & Mean \\
\hline 1 & Control & $306.08 \mathrm{f}$ & $343.33 \mathrm{~d}$ & 324.65 & $211.86 \mathrm{a}$ & $230.65 \mathrm{a}$ & 221.20 & $64.46 \mathrm{~d}$ & $79.9 \mathrm{c}$ & 72.18 \\
\hline 2 & $\begin{array}{c}\text { Humic at } \\
30 \mathrm{ml}\end{array}$ & $381 \mathrm{de}$ & $458.33 \mathrm{bc}$ & 419.65 & $222.92 \mathrm{a}$ & $236.96 \mathrm{a}$ & 229.90 & $84.81 \mathrm{c}$ & $108.71 \mathrm{bc}$ & 96.76 \\
\hline 3 & $\begin{array}{l}\text { Humic at } \\
60 \mathrm{ml}\end{array}$ & $397 \mathrm{de}$ & $405.33 \mathrm{~cd}$ & 401.15 & $224.51 \mathrm{a}$ & $251.93 \mathrm{a}$ & 238.20 & $89.14 \mathrm{c}$ & $102.70 \mathrm{bc}$ & 95.92 \\
\hline 4 & $\begin{array}{l}\text { Fulvic at } \\
50 \mathrm{ml}\end{array}$ & $435.67 \mathrm{~cd}$ & $514.67 \mathrm{ab}$ & 475.10 & $223.06 \mathrm{a}$ & $256.83 \mathrm{a}$ & 239.90 & $97.59 \mathrm{bc}$ & $132.2 \mathrm{ab}$ & 114.90 \\
\hline 5 & $\begin{array}{c}\text { Fulvic at } \\
100 \mathrm{ml}\end{array}$ & $499.67 \mathrm{~b}$ & $547 \mathrm{ab}$ & 523.00 & $215.49 \mathrm{a}$ & $242.8 \mathrm{a}$ & 229.10 & $107.39 \mathrm{~b}$ & $132.83 \mathrm{ab}$ & 120.05 \\
\hline 6 & $\begin{array}{c}\text { Humic at } \\
30 \mathrm{ml}+ \\
\text { Fulvic at } \\
50 \mathrm{ml}\end{array}$ & $471.67 \mathrm{bc}$ & $461.67 \mathrm{bc}$ & 466.60 & $225.16 \mathrm{a}$ & $248.1 \mathrm{a}$ & 236.60 & $106.35 \mathrm{~b}$ & $114.55 \mathrm{ab}$ & 110.40 \\
\hline 7 & $\begin{array}{c}\text { Humic at } \\
30 \mathrm{ml}+ \\
\text { Fulvic at } \\
100 \mathrm{ml}\end{array}$ & $400 \mathrm{de}$ & $469 \mathrm{bc}$ & 434.50 & $211.49 \mathrm{a}$ & $236.3 \mathrm{a}$ & 223.85 & $84.55 \mathrm{c}$ & $111.13 \mathrm{abc}$ & 97.83 \\
\hline 8 & $\begin{array}{c}\text { Humic at } \\
60 \mathrm{ml}+ \\
\text { Fulvic at } \\
50 \mathrm{ml}\end{array}$ & 344 ef & $451 \mathrm{bc}$ & 397.50 & $236.63 \mathrm{a}$ & $239 a$ & 237.80 & $81.48 \mathrm{c}$ & $107.40 \mathrm{bc}$ & 94.44 \\
\hline 9 & $\begin{array}{c}\text { Humic at } \\
60 \mathrm{ml}+ \\
\text { Fulvic at } \\
100 \mathrm{ml}\end{array}$ & $568.33 \mathrm{a}$ & $601.67 \mathrm{a}$ & 584.65 & $235.37 \mathrm{a}$ & $236.77 \mathrm{a}$ & 236.00 & $133.87 \mathrm{a}$ & $142.33 \mathrm{a}$ & 138.05 \\
\hline & LSD & 54.22 & 95.1 & --- & N.S & N.S & --- & 15.96 & 28.87 & --- \\
\hline
\end{tabular}

The data also presented no significant effect when humic at 30 or $60 \mathrm{ml}$ likewise sprayed tree with fulvic acid at $100 \mathrm{ml}$ gave high significant yield than using fulvic acid at $50 \mathrm{ml}$ the increment on number of fruit per tree may be due to increasing fruit set per tree and reducing total dropping of fruits during the seasons.

With regard to the effect of organic acids on fruit weight the data showed no significant effect had obtained on average fruit weight of trees as treated with humic or fulvic acid alone or in combination.

With regard the effect on yield data from table
(4) Showed that the application of both humic at $60 \mathrm{ml}$ with fulvic at 100 significantly increase $d$ the yield per tree during both seasons under the study. Furthermore, fulvic acid at 50 or $100 \mathrm{ml}$ gave a higher yield than adding humic acid at 30or $60 \mathrm{ml}$. the increment in yield may be due to the effect of both humic and fulvic acid on increasing the number of fruits per trees Since, the effect of fruit weight was non pronounced .

Humic acid is contains many elements which increasing the availability of trace minerals and consequently affected plant growth and yield 
(Hartwigson and Evans, 2000). The obtained result is in a harmony with those obtained by El-Mohamedy and Ahmed (2009), Sharaf, et al. (2011), Abd El-Razek et al. (2012), Elattar (2012), Abbas, et al., (2013)

Effect of humic and Fulvic acid on fruit juice and vitamin $C(\mathrm{mg} / 100 \mathrm{ml}$ juice) of Washington navel orange fruits:

Data from Tables (5) reveled that application of both humic and fulvic acid each alone or together gave no clear effect on average fruit juice than the control whereas the data also, presented that adding humic acid at $30 \mathrm{ml}$ with fulvic acid at $100 \mathrm{ml}$ gave a somewhat increment than the other treatment.

Data from Tables (5) showed that the effect of both humic or fulvic acid each alone or in a combination gave no pronounced effect in this respect. Whereas, adding fulvic acid at 50 or $100 \mathrm{ml}$ gave a higher effect than adding humic acid each alone or with fulvic acid during the both seasons under the study.

Table 5. Effect of humic and Fulvic acid on fruit juice and vitamin $\mathrm{C}$ (mg/100 $\mathrm{ml}$ juice) of Washington navel orange fruits

\begin{tabular}{|c|c|c|c|c|c|c|}
\hline \multirow{2}{*}{ Treatments } & \multicolumn{3}{|c|}{ Juice $/ 100$ ml g } & \multicolumn{3}{|c|}{ Vit C (mg/100 ml juice) } \\
\hline & 2014 & 2015 & Mean & 2014 & 2015 & Mean \\
\hline 1 Control & $33.92 \mathrm{a}$ & $30.52 \mathrm{bc}$ & 32.22 & $46.5 \mathrm{~cd}$ & $54 \mathrm{~b}$ & 50.25 \\
\hline 2 Humic at $30 \mathrm{ml}$ & $31.43 \mathrm{a}$ & $26.29 \mathrm{e}$ & 28.86 & $46.37 \mathrm{~cd}$ & $56 \mathrm{ab}$ & 51.19 \\
\hline 3 Humic at $60 \mathrm{ml}$ & $34.3 \mathrm{a}$ & $27.48 \mathrm{de}$ & 30.89 & $51.13 \mathrm{abc}$ & $56.83 \mathrm{a}$ & 53.98 \\
\hline 4 Fulvic at $50 \mathrm{ml}$ & $34.50 \mathrm{a}$ & $27.12 \mathrm{bc}$ & 30.81 & $49 \mathrm{abc}$ & $57.33 \mathrm{a}$ & 53.17 \\
\hline 5 Fulvic at $100 \mathrm{ml}$ & $32.03 \mathrm{a}$ & $26.41 \mathrm{a}$ & 29.22 & $53.57 \mathrm{a}$ & $57 \mathrm{a}$ & 55.29 \\
\hline 6 Humic at $30 \mathrm{ml}+$ Fulvic at $50 \mathrm{ml}$ & $32.56 \mathrm{a}$ & $29.23 \mathrm{~cd}$ & 30.90 & $52.83 \mathrm{ab}$ & $57.17 \mathrm{a}$ & 55.00 \\
\hline 7 Humic at $30 \mathrm{ml}+$ Fulvic at $100 \mathrm{ml}$ & $34.99 \mathrm{a}$ & $29.55 \mathrm{~b}$ & 32.27 & $48.33 \mathrm{bcd}$ & $55.67 \mathrm{ab}$ & 52.00 \\
\hline 8 Humic at $60 \mathrm{ml}+$ Fulvic at $50 \mathrm{ml}$ & $31.07 \mathrm{a}$ & $30.98 \mathrm{bc}$ & 31.03 & $53.4 \mathrm{~d}$ & $56.5 \mathrm{ab}$ & 54.95 \\
\hline 9 Humic at $60 \mathrm{ml}+$ Fulvic at $100 \mathrm{ml}$ & $31.10 \mathrm{a}$ & $26.90 \mathrm{bcd}$ & 29.00 & $50.5 \mathrm{abc}$ & $56.33 \mathrm{ab}$ & 53.42 \\
\hline LSD & N.S & 2 & --- & 4.62 & 2.37 & --- \\
\hline
\end{tabular}

Furthermore, the same data showed that a somewhat increment on Vit $\mathrm{C}$ had obtained due to fulvic or humic acid application .Since, using fulvic and humic together increased Vit $\mathrm{C}$ content than the other treatment or the control .This results are agree with those obtained with Sharaf, et al. (2011), Abbas, et al., (2013), Mostafa et al.(2013), AbdEl-Hamid (2014), Abobatta (2015)
Effect of humic and Fulvic acid on SSC, acidity and SSC/acid ratio of Washington navel orange fruits:

Data from table (6) showed that the application of both humic or $\mathrm{c}$ acid each alone or together gave no pronounced effect on total soluble solid and total acidity in fruit juice. Whereas the increment on SSC/acid ratio increasing especially at the second seasons may be due to the reducing on total acidity in fruit juice. obtained result are similar to those reported by Somaa (2007), El-Boray et al. (2015)

Table 6. Effect of humic and Fulvic acid on SSC, acidity and SSC/acid ratio of Washington navel orange fruits

\begin{tabular}{|c|c|c|c|c|c|c|c|c|c|}
\hline \multirow{2}{*}{ Treatments } & \multicolumn{3}{|c|}{$\mathrm{SSC} \%$} & \multicolumn{3}{|c|}{ Total acidity } & \multicolumn{3}{|c|}{ SSc /acidity ratio(\%) } \\
\hline & 2014 & 2015 & Mean & 2014 & 2015 & Mean & 2014 & 2015 & Mean \\
\hline 1 Control & $11.37 \mathrm{bcd}$ & $11.73 \mathrm{ab}$ & 11.55 & $0.96 \mathrm{e}$ & $1.05 \mathrm{ab}$ & 1.01 & $11.9 \mathrm{a}$ & $11.24 \mathrm{bc}$ & 11.57 \\
\hline 2 Humic at $30 \mathrm{ml}$ & $11.1 \mathrm{~d}$ & $12.13 \mathrm{ab}$ & 11.62 & $1.01 \mathrm{de}$ & $0.92 \mathrm{~b}$ & 0.97 & $10.93 \mathrm{ab}$ & $13.32 \mathrm{a}$ & 12.13 \\
\hline 3 Humic at $60 \mathrm{ml}$ & $12.17 \mathrm{ab}$ & $12.07 \mathrm{ab}$ & 12.12 & $1.18 \mathrm{bc}$ & $1 \mathrm{ab}$ & 1.09 & $10.36 \mathrm{~b}$ & $12.12 \mathrm{abc}$ & 11.24 \\
\hline 4 Fulvic at $50 \mathrm{ml}$ & $11.93 \mathrm{abcd}$ & $11.7 \mathrm{ab}$ & 11.82 & $1.26 \mathrm{ab}$ & $1.03 \mathrm{ab}$ & 1.15 & $9.49 \mathrm{bc}$ & $11.41 \mathrm{bc}$ & 10.45 \\
\hline 5 Fulvic at $100 \mathrm{ml}$ & $11.73 \mathrm{abcd}$ & $11.8 \mathrm{ab}$ & 11.77 & $1.37 \mathrm{a}$ & $1.02 \mathrm{ab}$ & 1.20 & $8.54 \mathrm{c}$ & $11.54 \mathrm{abc}$ & 10.04 \\
\hline 6 Humic at $30 \mathrm{ml}+$ Fulvic at $50 \mathrm{ml}$ & $12.03 \mathrm{abc}$ & $11.8 \mathrm{ab}$ & 11.92 & $1.18 \mathrm{bc}$ & $1.08 \mathrm{a}$ & 1.13 & $10.21 \mathrm{~b}$ & $10.95 \mathrm{c}$ & 10.58 \\
\hline 7 Humic at $30 \mathrm{ml}+$ Fulvic at $100 \mathrm{ml}$ & $12.33 \mathrm{a}$ & $11.2 \mathrm{~b}$ & 11.77 & $1.16 \mathrm{bcd}$ & $1.08 \mathrm{a}$ & 1.12 & $10.63 \mathrm{ab}$ & $10.37 \mathrm{c}$ & 10.50 \\
\hline 8 Humic at $60 \mathrm{ml}+$ Fulvic at $50 \mathrm{ml}$ & $11.13 \mathrm{~cd}$ & $12.4 \mathrm{a}$ & 11.77 & 1.05 cde & $0.96 \mathrm{ab}$ & 1.01 & $10.61 \mathrm{ab}$ & $12.98 \mathrm{ab}$ & 11.80 \\
\hline 9 Humic at $60 \mathrm{ml}+$ Fulvic at $100 \mathrm{ml}$ & $11.4 \mathrm{bcd}$ & $11.8 \mathrm{ab}$ & 11.60 & $1.15 \mathrm{bcd}$ & $1.06 \mathrm{a}$ & 1.11 & $9.97 \mathrm{bc}$ & $11.09 \mathrm{c}$ & 10.53 \\
\hline LSD & 0.81 & 0.84 & --- & 0.15 & 0.12 & --- & 1.38 & 1.66 & ---- \\
\hline
\end{tabular}

\section{CONCLUSION}

From this study it is clear that drenching soil of Washington navel orange trees with humic or fulvic acid each alone or together improving the fruit set percentage. Furthermore, reduced the preharvest drop increasing yield and number of fruits/tree especially at the rate of (humic acid at $30 \mathrm{ml}$ plus fulvic acid at 60 $\mathrm{ml}$ ). Whereas adding humic or fulvic acid gave un pronounced effect on total soluble solid, total acidity and SSC/acid ratio in fruit juice but gave a some increment in Vit $\mathrm{C}$ than the other control.

\section{REFERENCES}

Abbas, T., S. Ahmad, M. Ashraf, M. A. Shahid, M. Yasin, R. M. Balal, M. A. Pervez and S. Abbas (2013). Effect of humic and application at different growth stages of kinnow mandarin (Citrus reticulata Blanco) on the basis of physio-biochemical and reproductive responses. Academia Journal of Biotechnology 1(1): 14-20. 
Abd El -hamied, S. A. A. (2014). Response of Valencia Orange to Some Natural and Synthetic Soil Conditioners under North Sinai(Egypt) Conditions Introduction .International $\mathrm{J}$ of Advanced Res. 2: 802-810

Abd El-Razek, E., Abd-Allah, A. S. E. and Saleh, M. M. S. 2012. Yield and fruit quality of Florida Prince peach trees as affected by foliar and soil application of humic acid. J. Appl. Sci. Res. 8(12): 5724- 5729.

Abobatta, W.F.R (2015). Improving growth and fruiting of Valancia orange trees under salinity condition by Magnetic iron and humate compound. Master thesis. Menofia .Univ.pp:1-160.

Andriesse, J.P. ( 1988). Nature and management of tropical peat soils. FAO Soils Bulletin No. 59, United Nations, Rome, 165.

AOAC (1995). Official methods of analysis. Association of Official Agricultural Chemists, 15th Ed. Washington, DC, USA, pp: 490-510.

Arancon, NQ, Edwards CA, Lee S, Byrne R (2006). Effects of humic acids from vermicompost on plant growth. Eur. J. Soil Biol. 42:S65-S69.

Cacco, G. and G. Dell Agnolla (1984). Plant growth regulator activity of soluble humic substances. Can. J. Soil Sci., 64: 25-28.

Duncan,D.B.(1965).multiple range and multiple $-\mathrm{F}$ test.Biometrics, 11:1-42.

Elatar , A.N.A. (2012). Effect of some organic compounds on date palm. M.Sc. Thesis, Fac. Agric. Mansoura Univ.

El-Boray, M. S. S, M. F. M. Mostafa, M.M. Abd El-Galel and I. A. I.Somaa (2015) Effect of humic and fulvic acids with some nutrients at different time of application on yield and fruits quality of Anna apple trees. J. Plant Production, Mansoura Univ., Vol. 6 (3):307 -321

El-Mohamedy, R. S. R and Ahmed, M. A. (2009). Effect of biofertilizers and humic acid on control of dry root rots disease and improvement yield quality of Mandarin (Citrus reticulate Blanco). Res. J. Agric. \& Biol. Sci., 5(2):127-137. 69

EL- Nabawy, S.M.; EL-Barkouki and EL-Hammady, A. (1967). Studies on artificial colouring and storage of Egyptian mandarins. Second Arab. Hort. Cong.

Fathy, M, A., Gabr, M. A. and El-Shall, S. A. 2010. Effect of humic acid treatments on "Canino" apricot growth, yield and fruit quality. New York Science J, 3(12):109-115.

Fayed, T.A. 2010. Optimizing yield, fruit quality and nutrition status of Roghiani olives grown in Libya using some organic extracts, J. Hort. Sci. \& Ornamen. Plants 2 (2): 63-78.

Hartwigson, J.A. and M.R. Evans (2000). Humic acid seed and substrate treatments promote seedling root development. HortScience, 35(7): 1231-1233.

Ishac, Y. Z. (1989). Inoculation with associative N2-fixers Egypt. Nitrogen fixation with non-legumes, Kluwer Academic Publishers. Pp. 241-246.

MacCarthy, P., R. Malcolm, C. Clapp, and P. Bloom (1990). An introduction to soil humic substances. In Humic substances in soil and crop sciences, eds. P. MacCarthy, C. Clapp, R. Malcolm, and P. Bloom, 1-12. Madison, WI: ASA-CSSA.
Malcolm, R. L. (1990). Variations between humic substances isolated from soils, stream waters, and groundwater as revealed by ${ }^{13} \mathrm{C}-\mathrm{NMR}$ spectroscopy. In Humic substances in soil and crop sciences, eds. P. MacCarthy, C. Clapp, R. Malcolm, and P. Bloom, 13-35. Madison, WI: ASA-CSSA

Ministry of Agriculture (2014). Bull. Agric. Economic and Statistics- Ministry of Agriculture and Land Reclamation of Egypt.

Mosa, W., EL-Megeed, N., \& Paszt, L. (2015). The Effect of the Foliar Application of Potassium, Calcium, Boron and Humic Acid on Vegetative Growth, Fruit Set, Leaf Mineral, Yield and Fruit Quality of "Anna" Apple Trees. American J of Experimental Agriculture.

Mustafa, N.S and S.M. El-Shazly (2013) Impact of some biostimulant substances on growth parameters of Washington Navel orange trees. J. Applied Sci. Res, 3(4): 156-160.

Nardi, S., D. Pizzeghello, A. Muscolo and A. Vianello (2002). Physiological effects of humic substances on higher plants. Soil Biol. Biochem., 34: 15271536.

Poincelot, R.P. (1993). The use of a commercial organic biostimulant for bedding plant production. J. Sustainable Agriculture, 3 (2): 99-110.

Rodriguez,J.G.(2000).Effect of vinasse on sugercane (Saccharumofficinarum) productivity.Rev.Fac.Agron.,17:318-326.

Russo, R.O. and G.P. Berlyn (1992). Vitamin-humic-algal root biostimulant increases yield of green bean. HortScience, 27 (7): 847.

Saber, S. M. (1993). The use of multi-strain bio-fertilizer in agriculture. Theory and pratice. Proc. Sixth International Symposium on Nitrogen Fixation with Non-legumes, Ismailia, Egypt, p.61.

Salem, A.T., Fayed, T.A., Hagagg, L. F., Mahdy, H. A. and ElShall, S. A. (2010). Effect of rootstocks, organic matter and different nitrogen levels on growth and yield of Le-Cont Pear trees. J. Hort. Sci. \& Ornamen. Plants 2 (3): 130-147.

Schnitzer, M.,( 1982). Organic matter characterization. In: Page A.L., Miller R.H., Keeney D.R. (eds): Methods of Soil Analysis. Part 2. Chemical and Microbiological Properties. 2nd Ed. Soil Science Society of America, Madison, 581-594.

Senn, T.L. and A.R. Kingman (2000). A review of humus and humic acids. www. australianhumates .com, pp: 15 .

Sharaf, M. M., Bakry, K. A., \& EL-Gioushy, S. F. (2011). the Influence of Some Bio and Organic Nutritive Addenda on Growth, Productivity, Fruit Quality and Nutritional Status of Washington Navel Orange Trees. Egyptian Journal of Basic and Applied Sciences (Vol. 26).

Somaa, I. A. (2007) . Studies on the effect of humic acid on growth and fruiting of Anna apple under middle delta conditions. M.Sc. Thesis, Fac. Agric. Minufiya University 
Samra, N. R. et al.

تأثير إستخدام بعض الاسمده العضويه على العقد والتساقط و الإنتاجيه وجودة الثمار فى أشجار البرتقال ابوسره

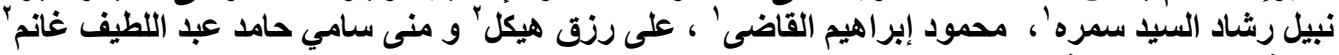

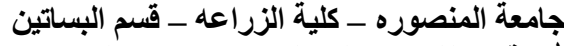

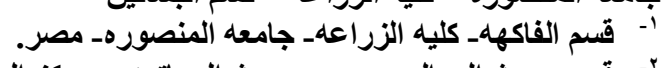

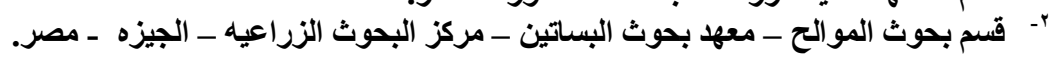

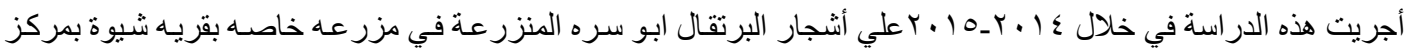

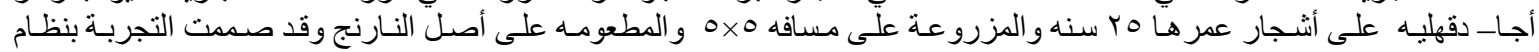

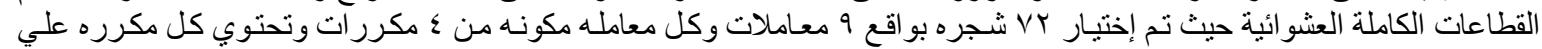

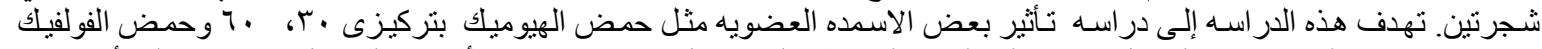

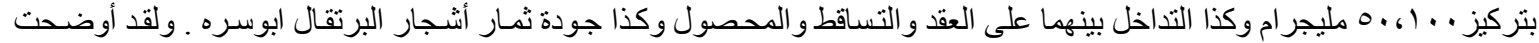

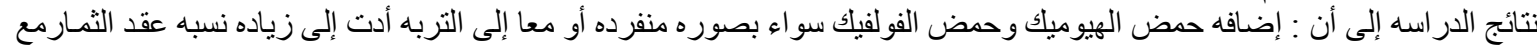

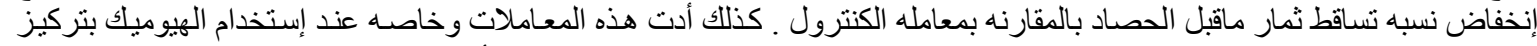

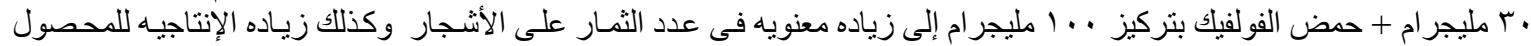

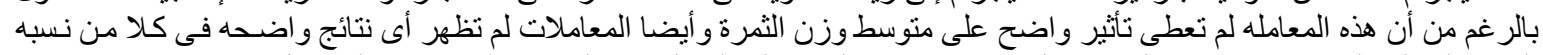

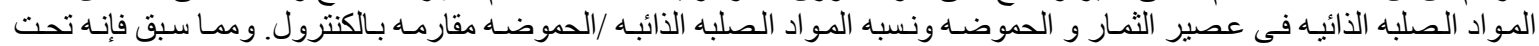

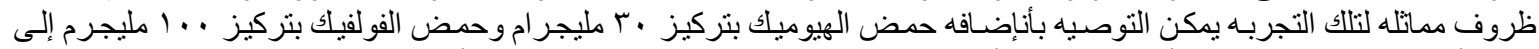

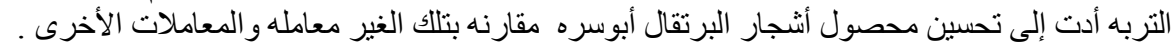

